\title{
DE CURAÇAOSCHE REALEN EN STUIVERS VAN 1821 EN 1822
}

DOOR

DR. J. W. A. VAN HENGEL

Op 16 November 1820 deed Schout bij Nacht Cantz'laar als Gouverneur van Curaçao en Onderhoorigheden zijn intrede. Hij trachtte spoedig maatregelen te nemen om het muntwezen op Curaçao, dat in dien tijd in een erbarmelijken toestand verkeerde, te verbeteren.

Hiertoe trad hij in verbinding met een financieele instantie, welke sinds eenige jaren op dit eiland bestond, nl. met de „Directie van het Fonds tot vernietiging der bewijzen van afgekeurde Johannissen" 1).

Op voordracht van deze Directie verleende de Gouverneur zijn goedkeuring aan het voorstel over te gaan tot invoering van zilveren Curaçaosche realen en stuivers, welke in de Vereenigde Staten van Noord-Amerika zouden worden gemunt.

Op 7 September 1821 gaven Directeuren aan den Gouverneur kennis van de ontvangst van 60.000 stuks realen, welke per brik „Eliza” uit New-York waren gearriveerd.

Na kennisgeving aan den Raad van Policie in zijn zitting van 18 September d.a.v. verscheen in de Curaçaosche Courant van 22 September 1821 de volgende Publicatie:

„De Schout bij Nacht Gouverneur en Raden van Policie van Curaçao en onderhoorige eilanden.

Allen den genen die deze zullen zien ofte hooren lezen, salut! doen te weten:

1) Voor een volledig overzicht van het Muntwezen op Curaçao in deze jaren zij verwezen naar: Mr. B. de Gaay Fortman, De WestIndische Gids, Deel 8, pag. 353 en Deel 10, pag. 251 alsmede naar het Artikel over het Curaçaosche Muntwezen van de hand van Mr. G. J. Fabius in De Economist van 1913, pag. 765 en naar de Encyclopaedie van Nederlandsch West-Indië, pag. 489. 
Nademaal Zijne Excellentie de Gouverneur, uit aanmerking van de ongewone schaarsheid aan klein geld, welke sedert langen tijd in deze kolonien, tot groote inconvenientie van het publiek is ondervonden, aan de Directie van het Fonds tot vernietiging der bewijzen van afgekeurde Johannissen, op derzelver voordragt, heeft toegestaan, om eene bepaalde som aan zilveren Schellingen of Realen te doen munten ten einde op dit en de onderhoorige eilanden in omloop te worden gebragt.

Is goedgekeurd en besloten: om de zilveren Realen of Schellingen bij de Directie van het Fonds tot vernietiging der bewijzen van afgekeurde Johannissen ontvangen en welke gemunt zijn zooals hierin zal worden beschreven, namelijk: aan de eene zijde bestempeld met het woord reaal en met de talletter 1 daarboven, welke omgeven zijn met eenen eiken tak ter regter en eenen laurier tak ter linker zijde; en aan de andere zijde met het woord Curaçao boven eenen staf van Merkuur en eenen maishalm kruislings over elkander, met het jaartal 1821 daaronder; op dit eiland en op de onderhoorige eilanden Bonaire en Aruba als een koloniale munt gangbaar te maken, ieder voor of tegen zes stuivers Curaçaosch Courant; wordende dus alle ende een iegelijk op dezelve eilanden bij deze gelast om de hiervoren beschrevene zilveren Realen of Schellingen tegen de voorzeide waarde aan te nemen en te ontvangen. Aldus gearresteerd in des Raads vergadering gehouden op het Gouvernements Huis, binnen het Fort Amsterdam op Curaçao den 18den September 1821, het achtste jaar van Zijner Majesteits regering.

De Gouverneur en Raden voornoemd,

Ter ordonnantie van dezelve,

(w.g.) Cantz'laar.

(w.g.) W. Prince, Sec.

Gepubliceerd binnen het Fort Amsterdam, in de Willemstad, op Pietermaai, Scharlo, en aan de Overzijde dezer Haven, op den 19den der gemelde maand.

(w.g.) W. Prince, Sec."

In zijn Rapport van 14 Jan. 1822 stelde de Gouverneur den Minister in het Moederland in kennis met de invoering dezer stukken, waarop deze laatste zich in zijn antwoord van 2 April d.a.v. hiermede accoord verklaarde. Blijkens een Rapport in 1826 aan den Minister uitgebracht door den Kapitein-Adjudant van den Gouverneur, R. F. van Raders, in verband met de voorgenomen invoering van het Ned. muntstelsel op Curaçao, moet 
echter in 1821 het dubbele aantal realen, dus 120.000 stuks, in omloop zijn gebracht.

Op 7 Aug. 1822 volgde een schrijven van bovengenoemde Directie waarin werd kennis gegeven van de aankomst van 150.000 stuivers per brik „Hippomenes.' uit New-York. In de vergadering van den Raad van Policie van 13 Aug. d.a.v. deed de Gouverneur hiervan mededeeling, terwijl de Curaçaosche Courant van 17 Aug. 1822 de volgende Publicatie 1) hieromtrent bevat. „De Schout bij Nacht Gouverneur en Raden van Policie van Curaçao en onderhoorige eilanden. Allen den genen die deze zullen zien of hooren lezen, salut! doen te weten:

Nademaal het raadzaam en hoog noodig geoordeeld is eene bepaalde som aan nieuwe stuivers op dit en de onderhoorige eilanden, tot gerijf der ingezetenen, gangbaar te maken; waardoor niet alleen voorzien wordt in de groote schaarsheid welke, sedert een geruimen tijd, aan die soort van kleingeld ondervonden is, maar tevens ook de thans nog in circulatie zijnde stuivers, zonder inconvenientie van het publiek, kunnen ongangbaar verklaard worden.

Is goedgevonden en besloten:

1. De hiervorenbedoelde nieuwe stuivers die gemunt zijn zooals hierin omschreven wordt namelijk: aan de eene zijde het talletter 1 boven op het woord Stuiver en aan de andere zijde het Jaartal 1822 met het woord Curaçao, op dit en de onderhoorige eilanden Bonaire en Aruba als koloniale munt gangbaar te maken, tegen acht en veertig stuivers per pezo van achten of zes stuivers voor eene zilveren reaal of schelling; tegen welken koers de gemelde stuivers door allen ende een iegelijken op de gemelde eilanden zullen moeten ontvangen en aangenomen worden.

2. De stuivers die thans in circulatie zijn, van en na de afkondiging dezer wet op dit en de onderhoorige eilanden, ongangbaar te verklaren, zooals dezelve bij deze ongangbaar worden verklaard; zullende dus geene andere dan de in $\S 1$ vermelde stuivers op de gemelde eilanden in omloop mogen wezen.

3 . Kennelijk te maken dat de nieuwe gangbare stuivers op morgen den 14den dezer en volgende dagen ten Kantore van het Fonds tot vernietiging der bewijzen van afgekeurde Johannissen aan de genen die zulks zullen verlangen in kleine sommen zullen worden verwisseld voor ander alhier te Lande gangbaar geld.

1) Zie ook Publicatieblad van Curaçao 13-14 Aug. 1822, No. 60; bij de invoering der realen is niet een Publicatieblad uitgegeven. 
Aldus gearresteerd in des Raads vergadering gehouden op het Gouvernements Huis, binnen het Fort Amsterdam op Curaçao den 13den Augustus 1822, het negende jaar van Zijner Majesteits Regering.

De Gouverneur en Raden voornoemd,

Ter ordonnantie van dezelve,

$$
\text { (w.g.) Cantz'laar. }
$$

(w.g.) W. Prince, Sec.

Gepubliceerd binnen het Fort Amsterdam, en in de Willemstad, op Pietermaai, Scharlo en aan de Overzijde dezer Haven, den 14den der gemelde maand.

$$
\text { (w.g.) W. Prince, Sec." }
$$

Volgens Artikel 3 van bovengenoemde Publicatie konden de stuivers ten kantore van het Fonds tot vernietiging der bewijzen van afgekeurde Johannissen worden verwisseld voor ander gangbaar geld; hieruit blijkt de bijzondere plaats welke de Directie van bovengenoemd Fonds in die dagen innam bij zaken die het Curaçaosche Muntwezen betroffen. Tot nu toe is het ons echter niet gelukt bijzonderheden omtrent deze beide muntslagen in Amerika en omtrent de wijze waarop zij tot stand kwamen, in eenig Archief te vinden. Waarschijnlijk zijn we niet ver bezijden de waarheid indien we veronderstellen dat een en ander door mondeling overleg tusschen den Gouverneur en Directeuren van het Fonds tot vernietiging der bewijzen van afgekeurde Johannissen heeft plaats gehad. Zoo lezen wij b.v. in het GouvernementsJournaal van 1821 onder 31 Januari No. 112: „Heden hebben wij met de Directeuren van het Fonds gebesoigneerd wegens het realiseeren der muntspecien", terwijl bij de Publicatie van 3/4 Januari 1821 reeds bekend was gemaakt ,dat de Gouverneur geinviteerd en gemagtigd is, om over de zaken van het Fonds tot vernietiging der bewijzen van afgekeurde Johannissen, buiten nadere concurrentie van den Raad van Policie zoodanig te handelen als hij Gouverneur tot welzijn der kolonie, best raadzaam zal oordeelen en bevinden te behooren; waarna slechts kennisgeving aan dezen Raad zal behoeven te worden gedaan."

Op 8 Nov. 1822 wordt nogmaals de aankomst van stuivers, thans van 210.000 stuks per brik „Hippomenes” uit New-York gemeld onder bijvoeging tevens van de voor den muntslag der stuivers en realen gebruikte stempels.

Hiervan deed de Gouverneur mededeeling aan den Raad van Policie in de zitting van 19 November 1822. 
Bij Kon. Besluit van 10 Mei 1826 lit. A werd op Curaçao met ingang van 1 Jan. 1827 het Ned. muntstelsel volgens de Wet van 28 Sept. 1816 No. 50 ingevoerd. Hierbij zijn de in 1821 ingevoerde realen ongangbaar verklaard ${ }^{1}$ ), terwijl bovengenoemde stuivers tegen een waarde van $2 \frac{1}{2}$ cent gangbaar bleven.

In latere jaren heeft van deze stuivers dan ook nogmaals een aanmunting plaats gehad, doch thans in de Munt te Utrecht, waarmede de eerste muntslag voor de Kolonie Curaçao tijdens het Koninkrijk der Nederlanden tot stand kwam; de muntslag vond plaats in 1841 .

Eenige jaren tevoren, nl. in 1838, had men zich op Curaçao zelf geholpen om in de dringende behoefte aan pasmunt te voorzien door 6000 Ned. guldens in 4 deelen te kappen en, na stempeling met een stempel $\mathrm{C}$, elk $1 / 4$ deel voor $f 0.25$ in circulatie te brengen ${ }^{2}$ ).

Op 13 Juli 1840 verzocht echter de Gezaghebber van Curaçao den Gouverneur-Generaal der West-Indische Bezittingen om den Minister van Marine en Koloniën te verzoeken over te gaan tot een muntslag van Curaçaosche stuivers, onder bijvoeging van een drietal dezer, in Nederland onbekende stukken.

Ter voldoening aan dit verzoek ontving het College van Raden en Generaal meesteren der Munt een schrijven d.d. 11 Dec. 1840 van den Minister van Financiën, waarin een muntslag van Curaçaosche stuivers werd voorgesteld tot een bedrag van $f$ 4000.onder bijvoeging van een exemplaar der gemelde stuivers, waarvan 40 stuks een innerlijke waarde van $f$ 1.- moesten hebben. Door de onbekendheid met deze stukken moest eerst een onderzoek naar gewicht en gehalte worden ingesteld. Nadat den Minister de uitkomsten hiervan waren medegedeeld kwam bij Kon. Besluit van 20 Januari 1841 No. 139 de machtiging af om tot een muntslag van $f 4000$.- aan stuivers over te gaan. Het gehalte der stukken is hierin vastgesteld op 300 duizendsten met een ruimte van 5 duizendsten boven en beneden deze waarde, terwijl het gewicht gemiddeld 0,675 Gram moest bedragen, zoodat 1482 stukken in 1 K.G. gingen. Het jaartal op de stukken moest 1822 zijn, zoodat de stukken zich dus in niets van die der vorige aanmunting in de Vereenigde Staten van Noord-Amerika onderscheiden zouden. Daar de stempels opnieuw moesten worden

1) Op 24 Aug. 1827 zijn deze stukken, met andere ongangbaar verklaarde munten, ter vermunting aan de Munt te Utrecht ontvangen; het gehalte bleek 898 duizendsten te bedragen.

2) Publicatieblad 8 Juni 1838, No. 212. 
aangemaakt, ontvingen de Stempelsnijders hiertoe een bedrag van $f$ 200.- .

Ter voldoening aan het Kon. Besluit zijn op 8 en 15 Juni 1841 de stuivers in een aantal van 169.007 stuks opgebracht ${ }^{1}$ ) en op 24 Juni d.a.v. ter verscheping naar den Magazijnmeester voor Koloniën te Amsterdam verzonden.

Als uitvloeisel van de bij Publicatieblad van 21 April 1854 no. 12 ingevoerde Wet van 14 Dec. 1853 No. 126 tot regeling van het Muntwezen in de West-Indiën is in dit jaar aan verschillende muntspeciën ingetrokken en in 1855 naar het Moederland verzonden voor een bedrag van $f 96.151 .75$, w.o. voor een bedrag van $f 2990.375$ aan bovenbeschreven stuivers.

Toch vermeldt het Koloniaal Verslag van 1882 voor Curaçao wederom dat als pasmunt in omloop zijn de $1 / 5$ deelen van Spaansche pilaardaalders en de $1 / 4$ deelen van Ned. guldens. Het heeft dan ook nog tot het begin der 20e eeuw geduurd alvorens op Curaçao definitief het Muntwezen is verbeterd.

Utrecht, 's Rijks Munt, Mei 1938.

1) Dit aantal is grooter dan het oorspronkelijk vastgestelde bedrag van 160.000 stuks, doch droeg de goedkeuring van den Minister. 